\title{
Characterisation and biodegradation of settleable organic matter for domestic wastewater
}

\author{
Derin Orhon*, Didem Okutman and Güçlü Insel \\ Environmental Engineering Department, Istanbul Technical University, I.T.Ü. Insaat Fakültesi, 80626 Maslak, Istanbul, Turkey
}

\begin{abstract}
Biodegradation of settled COD is studied by evaluating the associated OUR profile obtained in an aerated batch reactor. Hydrolysis was selected, as in current modelling, as the rate-limiting step for $\mathrm{O}_{2}$ consumption. Settled COD was found to incorporate a significant fraction of active biomass that needs to be accounted for in the evaluation. The analysis of the OUR profile yielded a significantly slower hydrolysis mechanism for settled COD, compared to its soluble slowly biodegradable counterpart.
\end{abstract}

\section{Nomenclature}

$\mathrm{b}_{\mathrm{H}} \quad=$ endogenous decay rate $\left[\mathrm{d}^{-1}\right]$

$\mathrm{C}_{\mathrm{S} 1}=$ influent total biodegradable COD $[\mathrm{mg} \mathrm{COD} / \mathrm{l}]$

$\mathrm{C}_{\mathrm{S}} \quad=$ total biodegradable COD $[\mathrm{mg} \mathrm{COD} / \mathrm{l}]$

$\mathrm{C}_{\mathrm{T}}=$ influent total $\mathrm{COD}[\mathrm{mg} \mathrm{COD} / \mathrm{l}]$

$\mathrm{f}_{\mathrm{E}} \quad=$ inert fraction of endogenous biomass

$\mathrm{k}_{\mathrm{hS}}=$ maximum specific hydrolysis rate for soluble COD components $\left[\mathrm{d}^{-1}\right]$

$\mathrm{k}_{\mathrm{hX}}=$ maximum specific hydrolysis rate for particulate COD components $\left[\mathrm{d}^{-1}\right]$

$\mathrm{K}_{\mathrm{S}} \quad=$ half saturation constant for growth [mg COD/l]

$\mathrm{K}_{\mathrm{XS}}=$ hydrolysis half saturation constants for soluble COD components [gCOD/gcellCOD]

$\mathrm{K}_{\mathrm{XX}}=$ hydrolysis half saturation constants for particulate COD components [gCOD/gcellCOD]

$\mathrm{S}_{\mathrm{H} 1} \quad=$ influent rapidly hydrolysable COD [mg COD/l]

$\mathrm{S}_{\mathrm{I}} \quad=$ influent soluble inert COD [mg COD/l]

$\mathrm{S}_{\mathrm{S} 1}=$ influent readily biodegradable COD [mg COD/l]

$\mathrm{S}_{\mathrm{T} 1} \quad=$ influent total soluble $\mathrm{COD}[\mathrm{mg} \mathrm{COD} / \mathrm{l}]$

$\mathrm{SS} \quad=$ suspended solids $[\mathrm{mg} / \mathrm{l}]$

VSS $=$ volatile suspended solids $[\mathrm{mg} / \mathrm{l}]$

$\mathrm{X}_{\mathrm{F}} \quad=$ fixed solids [mg COD/l]

$\mathrm{X}_{\mathrm{H}}=$ active heterotrophic biomass [mg COD/l]

$\mathrm{X}_{\mathrm{II}}=$ influent particulate inert COD [mg COD/l]

$\mathrm{X}_{\mathrm{S}}=$ slowly biodegradable particulate $\mathrm{COD}[\mathrm{mg} \mathrm{COD} / \mathrm{l}]$

$\mathrm{X}_{\mathrm{sS}}=$ slowly biodegradable settleable $\mathrm{COD}[\mathrm{mg} \mathrm{COD} / \mathrm{l}]$

$\mathrm{X}_{\mathrm{T}}=$ total particulate $\mathrm{COD}[\mathrm{mg} \mathrm{COD} / \mathrm{l}]$

$\mathrm{Y}_{\mathrm{H}}=$ heterotrophic yield coefficient $[\mathrm{gcellCOD} /(\mathrm{gCOD})]$

OUR $=$ oxygen uptake rate $[\mathrm{mg} / \mathrm{l} \cdot \mathrm{h}]$

$\hat{\mu}_{\mathrm{H}} \quad=$ maximum heterotrophic growth rate $\left[\mathrm{d}^{-1}\right]$

\section{Introduction}

The success of nutrient removal in activated sludge systems mainly depends on the delicate balance between the organic carbon, nitrogen and phosphorus content of the wastewater. In this balance, the amount of organic carbon is only meaningful when it is

\footnotetext{
* To whom all correspondence should be addressed.

盖 +90212285 3855; fax: +90212285 3336;

e-mail: dorhon@srv.ins.itu.edu.tr

Received 23 February 2001; accepted in revised form 1 April 2002.
}

expressed in terms of various fractions with different mechanisms and rates of biodegradation. In this respect, COD fractionation has been introduced as a very useful tool for the evaluation of biological treatment processes (Henze, 1992).

Significant COD removal is achieved in the primary settling of domestic sewage. The settled portion has been subject to a few investigations: Hydrolysate dosing was found to improve the removal efficiency of biological nitrogen removal, especially for a BNR system operated with low $\mathrm{C} / \mathrm{N}$ and $\mathrm{C} / \mathrm{P}$ ratios (Brinch et al., 1994). Similarly, Andreasen et al. (1997) argued that low effluent $\mathrm{P}$ concentrations could be attained by using primary sludge hydrolysate in EBPR activated sludge systems. It is now a common understanding that this portion represents a potential additional organic carbon source for nutrient removal, where needed. It was also stated that limited fermentation of primary sludge, if properly controlled, could increase this potential, by converting COD into more easily biodegradable components (Hatziconstantinou et al., 1996; Bannister and Pretorius, 1998; Moser-Engeler et al., 1998). Process modifications were suggested to use this COD fraction for enhancing nutrient removal in multi-phased systems (Grady et al., 1999; Pitman, 1995). Little is known, however, about the character of this fraction other than it usually undergoes a slower biological breakdown than the rest of the organic particulate matter in domestic sewage. There is certainly a need for additional information on the biodegradation of settleable organics, as compared to other significant biodegradable COD fractions. This information is to be derived in the same conceptual framework that today sets the basis for the kinetic evaluation of domestic sewage. The collected information may then help to decide whether settleable COD may be considered as an indistinguishable part of the particulate slowly biodegradable COD, or else it needs to be identified as a new parameter on the basis of markedly different kinetic characteristics.

The objective of the study is to explore the biodegradation of settleable COD fraction in domestic sewage in a way that can be readily incorporated into current models as a model component. In this context, the paper intends to cover characterisation of settleable organics as a different COD fraction than the rest, based on its biodegradation (hydrolysis) rate. This assessment is routinely performed for other COD fractions under aerobic conditions and a correction factor is applied for anoxic conditions (Ekama et al., 1986; Henze et al., 1987).

This type of an assessment, derived from the kinetic interpretation of the oxygen uptake rate (OUR) data is also very important for the biological nutrient removal (BNR) process, 


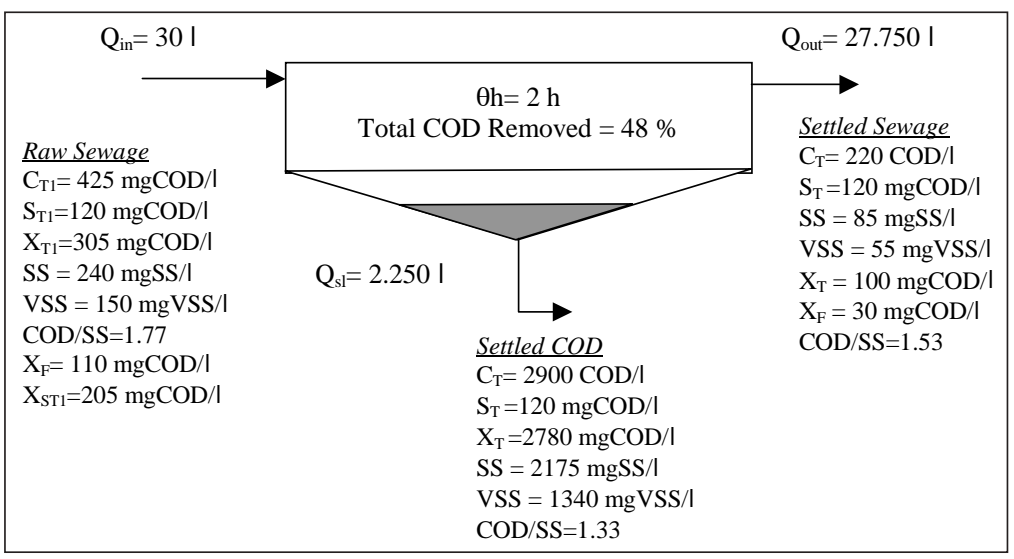

Figure 1

$C O D$ and solids mass balance for plain settling

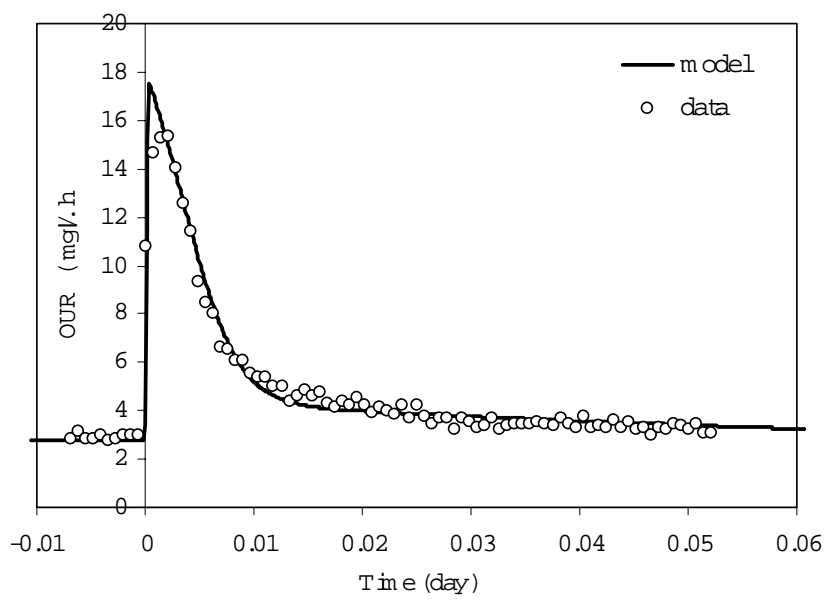

Figure 2

Model simulation for filtered sewage ( $F / M=0.05 \mathrm{gCOD} / \mathrm{gVSS}$ )

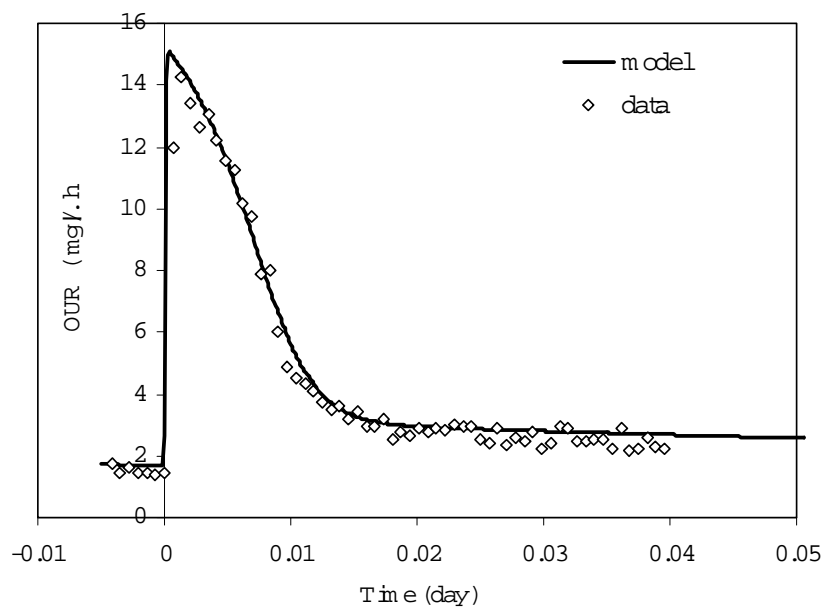

Figure 3

Model simulation for filtered sewage ( $F / M=0.1 \mathrm{gCOD} / \mathrm{gVSS}$ )

because it gives the appropriate indication of how fast the settleable fraction of the incoming COD will consume electron acceptors (nitrate) compared to the other fractions and the potential impact of its removal by primary settling to electron acceptor utilisation under aerobic and anoxic conditions.

\section{Materials and methods}

The experiments were conducted as part of a comprehensive characterisation survey on domestic sewage at the Ataköy plant, a small wastewater treatment facility in Istanbul (Okutman et al., 2002). A 30 I composite sample was collected from the influent of the treatment plant and subjected to a $2 \mathrm{~h}$ gravity settling in order to simulate the quality of fresh settled sewage. A $2.25 \mathrm{I}$ sample of the settled sewage fraction was withdrawn for further analysis. This volume, although quite diluted compared to full-scale operation, was required mainly for the OUR tests.

All analyses for conventional characterisation were performed as defined in Standard Methods, 1998. Soluble fraction was defined as the filtrate of the sample by vacuum filtration with cellulose acetate, $0.45 \mu \mathrm{m}$ membrane filters. The analytical survey also used Whatman GF/C glass-fibre filters for suspended solids, (SS), and volatile suspended solids (VSS), measurements. OUR measurements were conducted with a Manotherm RA-1000 continuous respirometer with PC connection. In the experiments, $\mathrm{pH}$ was kept in the range of 7.0 to 8.0 , suitable for biological activity. The OUR experiments were used for the assessment of the readily biodegradable COD and the evaluation of kinetic coefficients. The readily biodegradable COD fraction was determined according to the method proposed by Ekama et al., (1986). Biomass was seeded from parallel fill-and-draw reactors acclimatised to the same domestic sewage and operated at steady state, at a sludge age of $15 \mathrm{~d}$.

Testing of the experimental data was performed by means of sensitivity analysis and model simulation, using the AQUASIM computer program developed by the Swiss Federal Institute for Environmental Science and Technology (Reichert, 1994; Reichert et al., 1995). ASM1 (Henze et al., 1987) modified for endogenous decay (Orhon and Artan, 1994) was used for model evaluations.

\section{Results and evaluation}

\section{Characterisation and mass balance}

The evaluation was made on a daily-composite sample with a total $\mathrm{COD},\left(\mathrm{C}_{\mathrm{T}}\right)$, of $425 \mathrm{mg} / \mathrm{l}$, a typical value for sewage at the inlet of the Ataköy/Istanbul treatment plant (Okutman et al., 2002). Further analysis of the sample yielded a soluble COD fraction, $\left(\mathrm{S}_{\mathrm{T}}\right)$ of 120 $\mathrm{mg} / \mathrm{l}$ after filtration and a remaining particulate COD fraction $\left(\mathrm{X}_{\mathrm{T}}\right)$ of $305 \mathrm{mg} / \mathrm{l}$. The suspended solids, (SS), concentration was measured as $240 \mathrm{mg} / \mathrm{l}$, with a volatile fraction (VSS) of $150 \mathrm{mg} / \mathrm{l}$, corresponding to a $\mathrm{X}_{\mathrm{T}} / \mathrm{VSS}$ ratio of 2.03. These parameters are in agreement with the average characteristics of domestic wastewater ascertained for Istanbul (Orhon et al., 1997).

A two-hour plain settling was observed to achieve around $48 \%$ COD removal, reducing $\mathrm{C}_{\mathrm{T}}$ to $220 \mathrm{mg} / \mathrm{l}$ and $\mathrm{X}_{\mathrm{T}}$ to $100 \mathrm{mg} / \mathrm{l}$. This ratio, higher than the level commonly associated with the performance of primary settlers, should only be evaluated in conjunction with the sample analysed in the study. An SS reduction of $65 \%$ and a VSS reduction of $63 \%$ accompanied COD removal. These results further indicated that $205 \mathrm{mg} / \mathrm{l}$ of the COD in the raw sewage was of settleable nature, so that its total particulate COD content could be further subdivided into a suspended fraction of $100 \mathrm{mg} / \mathrm{l}$ and a settleable fraction of $205 \mathrm{mg} / \mathrm{l}$. The sludge fraction withdrawn for further analysis was $7.5 \%$ of the total settled sewage volume, quite diluted compared to full- scale operation, mainly to 


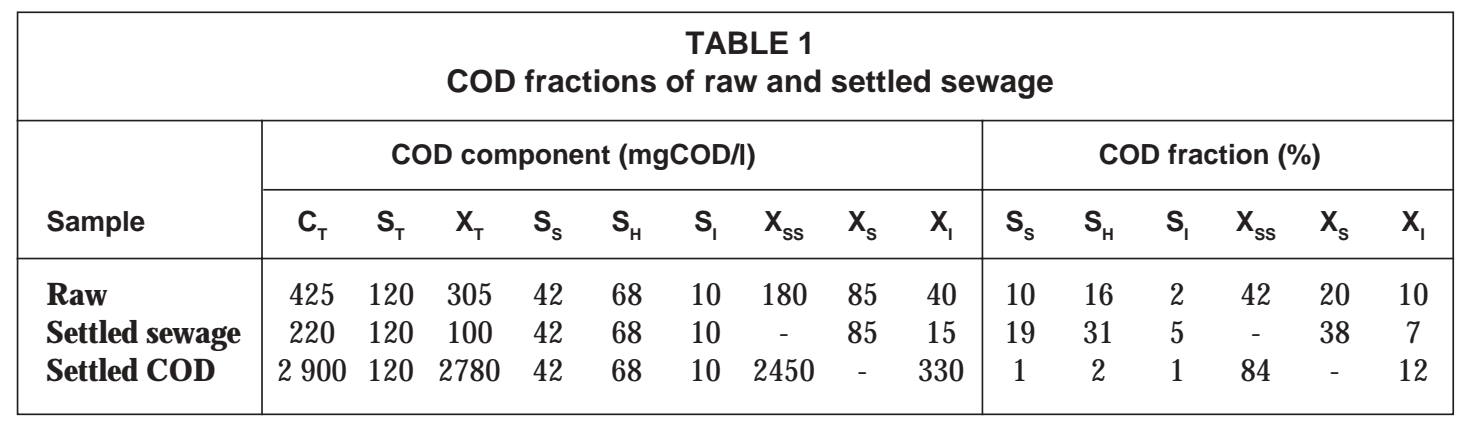

facilitate handling under laboratory conditions. In this volume, this fraction could be characterised with $\mathrm{C}_{\mathrm{T}}=2900 \mathrm{mg} / \mathrm{l}$ and $\mathrm{X}_{\mathrm{T}}=2780 \mathrm{mg} / \mathrm{l}$ as $\mathrm{S}_{\mathrm{T}}$ remained unchanged during settling. Mass balance of plain settling for parameters included in the evaluation is illustrated in Fig. 1.

\section{COD fractionation}

The settled volume includes by definition soluble COD fractions identical to those in the raw sewage and the settleable (settled) COD. In this context, soluble COD components were assessed by means of oxygen uptake, (OUR), measurements on the filtered sample. Two parallel tests (Runs 1 and 2) were carried out with an initial $\mathrm{S}_{\mathrm{S}}$ of $120 \mathrm{mg} / \mathrm{l}$ at two different $\mathrm{F} / \mathrm{M}$ ratios of 0.05 and $0.1 \mathrm{~g} \mathrm{COD} / \mathrm{g} \mathrm{VSS}$. A readily biodegradable COD concentration, $\left(\mathrm{S}_{\mathrm{S}}\right)$, of $42 \mathrm{mg} / \mathrm{l}$ could be calculated from the OUR profiles given in Figs. 2 and 3, in accordance with the method defined by Ekama et al. (1986), using a $\mathrm{Y}_{\mathrm{H}}$ value of $0.67 \mathrm{~g}$ cell $\mathrm{COD} / \mathrm{g}$ COD previously computed for the $42 \%$ same sewage.

Similarly, for the soluble $\left(\mathrm{S}_{\mathrm{I}}\right)$ and particulate $\left(\mathrm{X}_{\mathrm{I}}\right)$ inert COD fractions, $\mathrm{S}_{\mathrm{I}} / \mathrm{S}_{\mathrm{T}}$ and $\mathrm{X}_{\mathrm{I}} / \mathrm{X}_{\mathrm{T}}$ ratios of 0.08 and 0.15 respectively were adopted, as no specific measurements were made in this study for this purpose (Orhon et al.,1997). The soluble, $\left(\mathrm{S}_{\mathrm{H}}\right)$ and particulate, $\left(\mathrm{X}_{\mathrm{S}}\right)$, slowly biodegradable COD fractions were calculated from mass balance. The resulting COD fractionation, both for raw and settled sewage samples is outlined in Table 1.

These results, when compared with similar data also outlined in the table, reflect a typical domestic sewage composition with $88 \%$ biodegradable COD, including $10 \%$ readily biodegradable, $16 \%$ soluble and $62 \%$ particulate slowly biodegradable fractions. The experiments specifically indicated that around $180 \mathrm{mg} / \mathrm{l}$ of the particulate slowly biodegradable COD was of settleable nature.

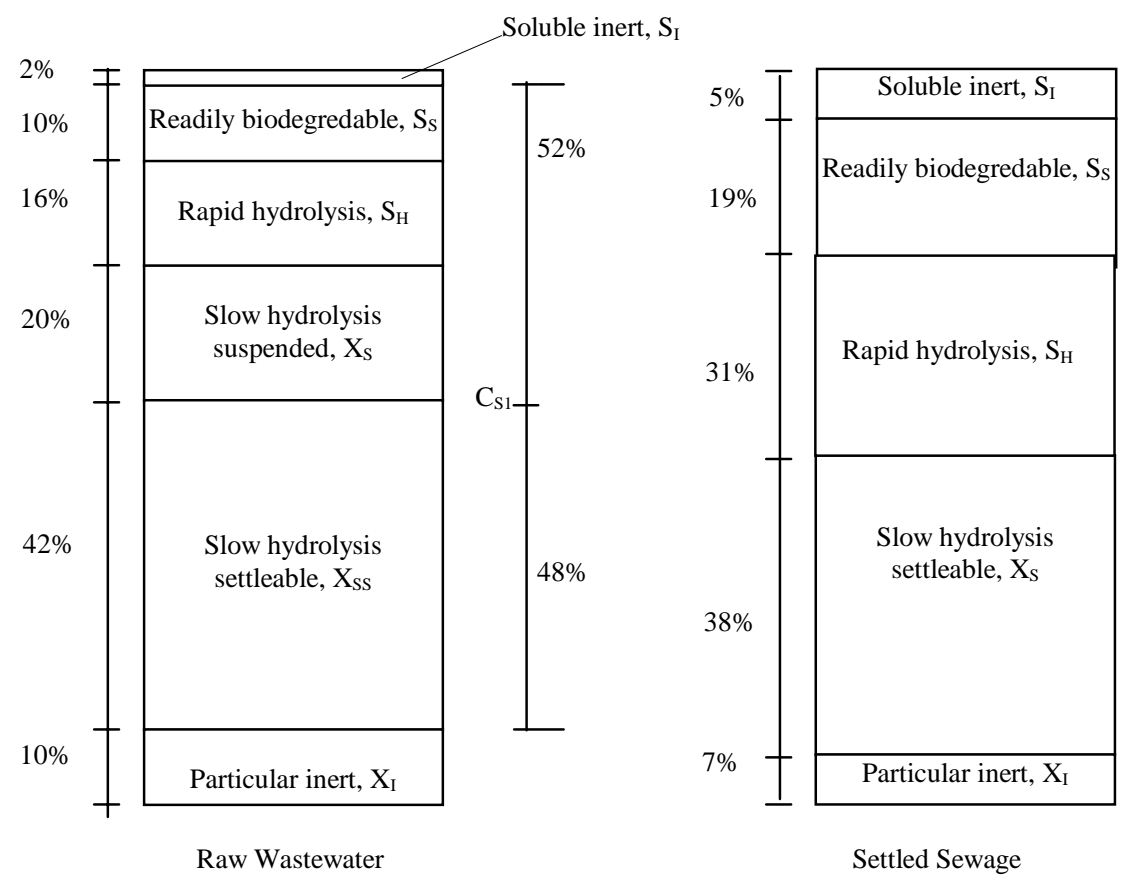

Figure 4

Schematic representation of COD fractionation for raw and settled sewage

Figure 5

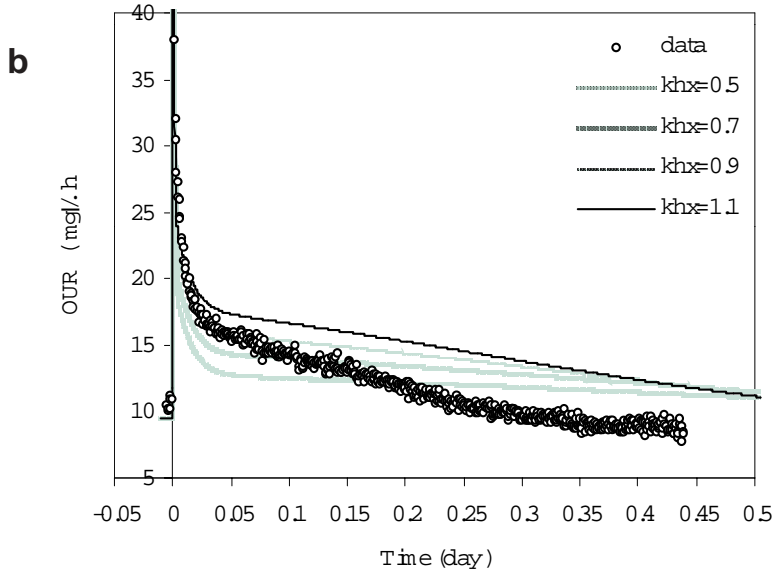

Calibration of the OUR profile in Run 3 (F/M ratio=0.06 gCOD/gVSS) for $X_{S S}=2450 \mathrm{mg} / \mathrm{l}$; (a) $K_{h x}=1.1$ (b) $k_{x x}=0.2$ 
a

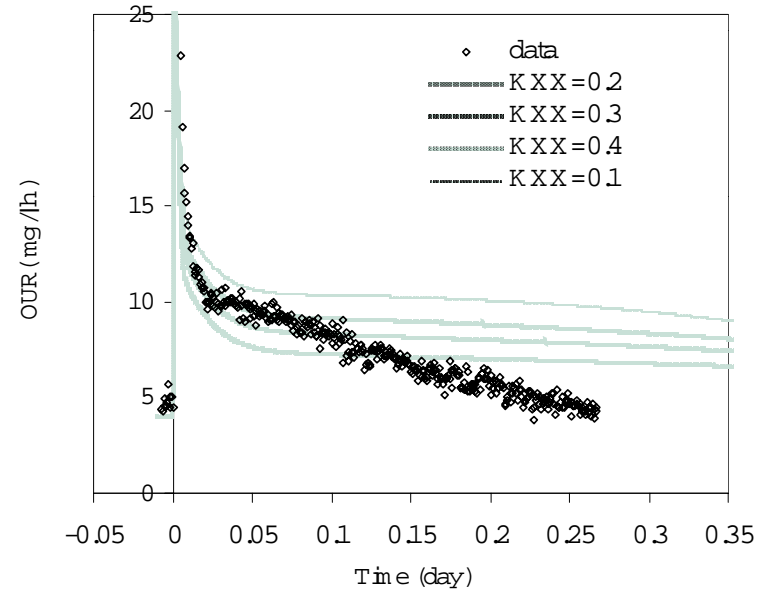

b

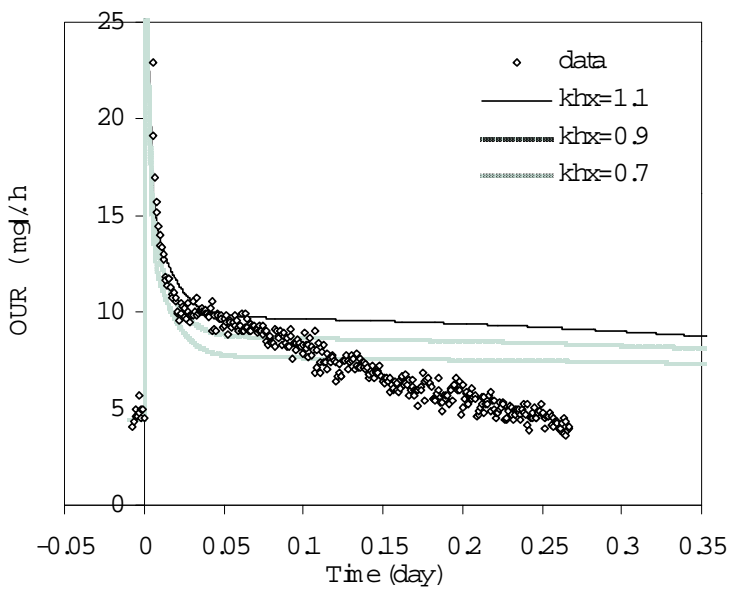

Figure 6

Calibration of the OUR profile in Run 4 (F/M ratio=0.15 gCOD/gVSS) for $X_{S S}=2450 \mathrm{mg} / \mathrm{l}$; (a) $k_{h x}=1.1$ (b) $K_{x x}=0.2$

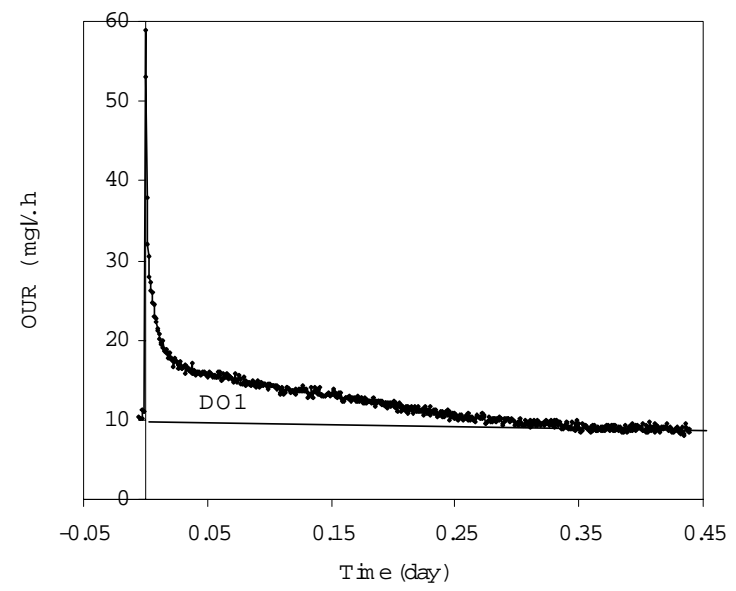

b

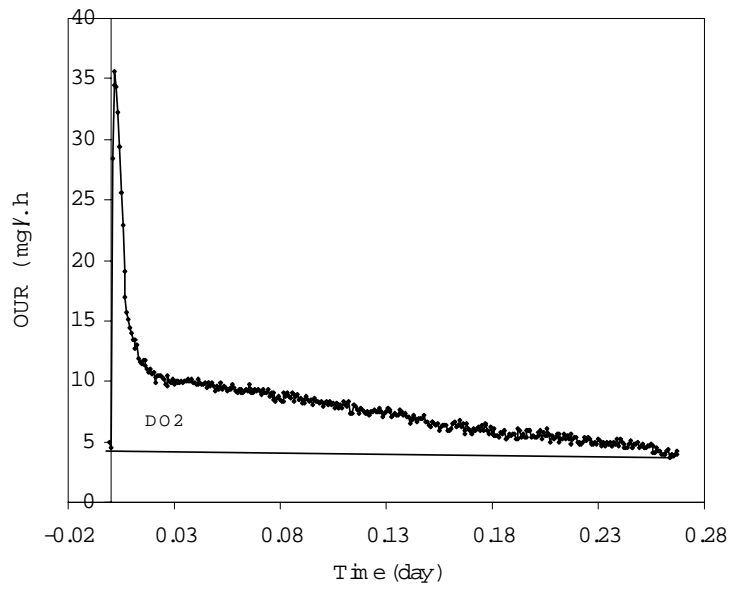

Figure 7

Experimental assessment of particulate biodegradable COD (a) for Run 3, (b) for Run 4

a

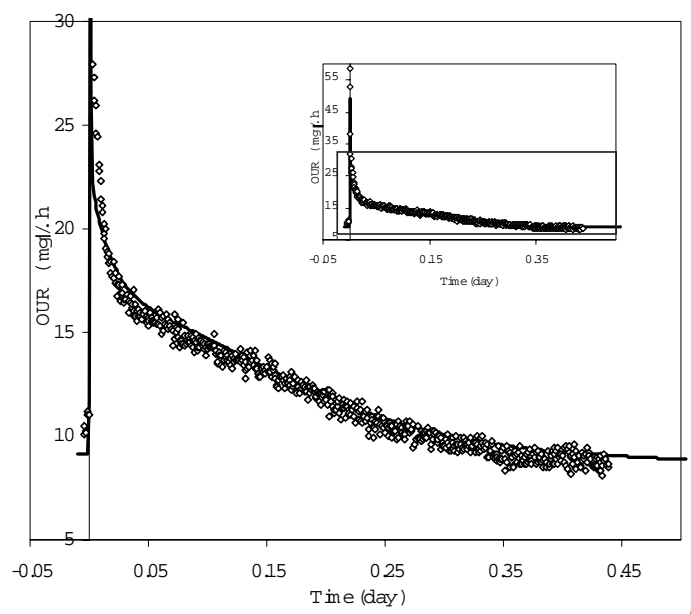

b

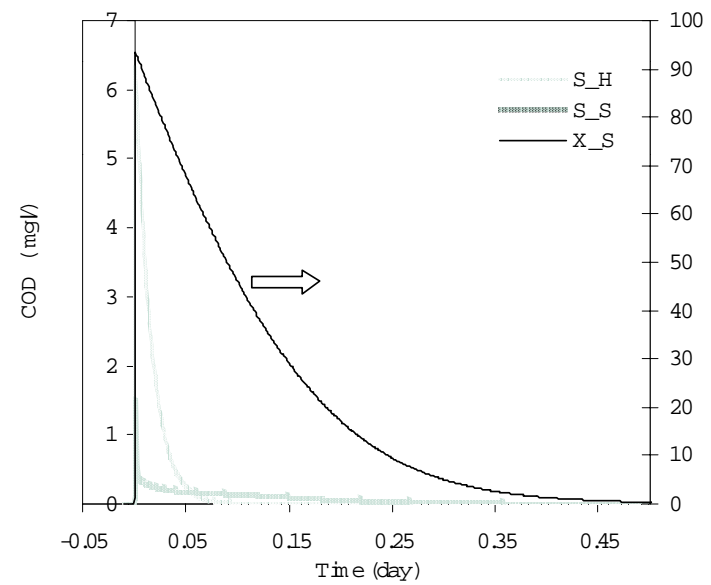

Figure 8

Model simulation of the OUR profile and biodegradable COD concentrations for Run 3 (a) OUR profile (b) biodegradable COD concentrations

The COD fractions associated with both raw and settled sewage samples also show (as illustrated in Fig. 4), that $48 \%$ of the biodegradable COD may potentially be removed by primary settling.

\section{Characteristics of the settleable COD}

The effect of primary settling on the electron acceptor utilisation potential of sewage much depends on the biodegradation characteristics of the settleable COD. These characteristics, if any different from the ones associated with the conventional slowly biodegradable fraction, may be a significant attribute for the recognition of the settleable COD as a new parameter in the modelling of activated sludge systems.

In this context, the OUR of the settleable COD fraction was 


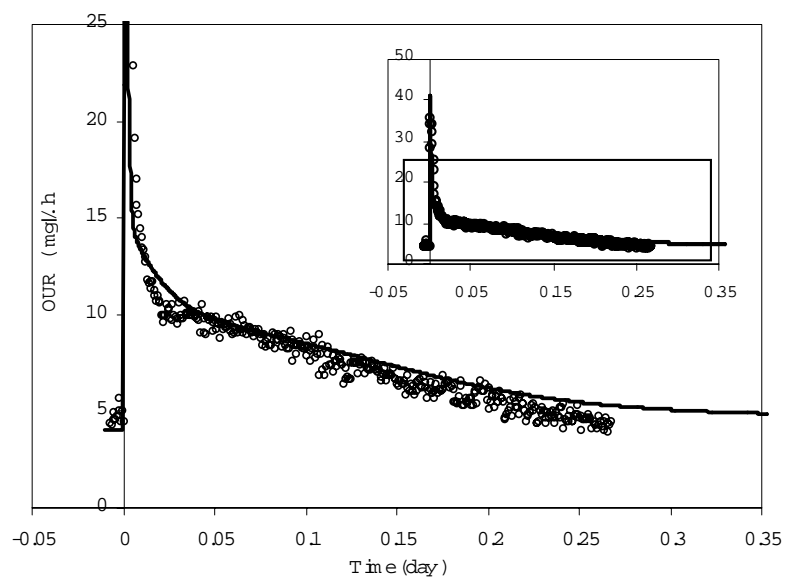

Figure 9

Model simulation of the OUR profile for Run 4

investigated on the settled sewage sample, with two consecutive tests carried out at different F/M ratios of 0.06 and $0.15 \mathrm{~g} \mathrm{COD} / \mathrm{g}$ VSS. These values were calculated on the assumption that the entire particulate COD capable of consuming oxygen was slowly biodegradable substrate only. In other words, the settled sewage was assumed to contain no appreciable active heterotrophic biomass, $\mathrm{X}_{\mathrm{H}}$. From basic experimental data, the initial particulate biodegradable COD of the sample in the first test $(\mathrm{F} / \mathrm{M}=0.06 \mathrm{~g}$ $\mathrm{COD} / \mathrm{g}$ VSS) was calculated as $2450 \mathrm{mg} / \mathrm{l}$. The second test with a higher F/M ratio was started $2 \mathrm{~d}$ after the sample was taken. This period was found to affect the COD content of the sample by around $20 \%$, due to biological decomposition of substrate under anaerobic conditions during storage in the laboratory. As shown in Figs. 5 and 6 , both runs exhibit a descending OUR profile after a narrow peak due to consumption of the soluble COD. The main part of the OUR profile is to be evaluated in terms of a hydrolysis mechanism, commonly accepted in the current modelling approach. As shown in these figures, calibration of the experimental data was not possible with the adopted model structure for a wide range of $\mathrm{k}_{\mathrm{h}}$ and $\mathrm{K}_{\mathrm{X}}$ values describing the hydrolysis kinetics. A closer inspection indicated that the misfit between experimental data and model simulation could largely be attributed to the fact that the initial slowly biodegradable COD level of $2450 \mathrm{mg} / \mathrm{l}$ adopted for the evaluation was too high for calibration.

From a conceptual standpoint, the area under the OUR profile, when continued long enough to reach the endogenous respiration stage, yields the total biodegradable COD consumed in the experiment. When analysed according to the same conceptual approach used for the assessment of $\mathrm{S}_{\mathrm{S}}$, the total $\mathrm{O}_{2}$ consumption for the experiment with an F/M of $0.06 \mathrm{~g} \mathrm{COD} / \mathrm{g}$ VSS excluding endogenous respiration, corresponds to an initial COD concentration of $1020 \mathrm{mg} / \mathrm{l}$, excluding the soluble biodegradable COD components (Fig. 7a). This analysis explains the discrepancy between experimental data and model outputs and indicates the need for a further segregation of the settled COD into slowly biodegradable $\mathrm{COD}, \mathrm{X}_{\mathrm{SS}}=1020 \mathrm{mg} / \mathrm{l}$ and active heterotrophic biomass, $\mathrm{X}_{\mathrm{H}}=1430$ $\mathrm{mg} / \mathrm{l} \mathrm{COD}$. The latter is often included as a model component, as part of the influent COD (Solfrank and Gujer, 1991; Henze, 1992). A similar evaluation for the second run yields, as shown in Fig.7b, a lower $\mathrm{X}_{\mathrm{SS}}$ level of $600 \mathrm{mg} / \mathrm{l} \mathrm{COD}$.

Model evaluation with the corrected initial $\mathrm{X}_{\mathrm{SS}}$ and $\mathrm{X}_{\mathrm{H}}$ values, provided good agreement with the experimental OUR profiles. Figure 8 illustrates the model calibration secured for the first test, for $\mathrm{a}_{\mathrm{hX}}$ of $0.7 \mathrm{~g} \mathrm{COD} / \mathrm{g} \mathrm{COD.d} \mathrm{and} \mathrm{K}_{\mathrm{xx}}$ of $0.05 \mathrm{gCOD} / \mathrm{g}$ COD.

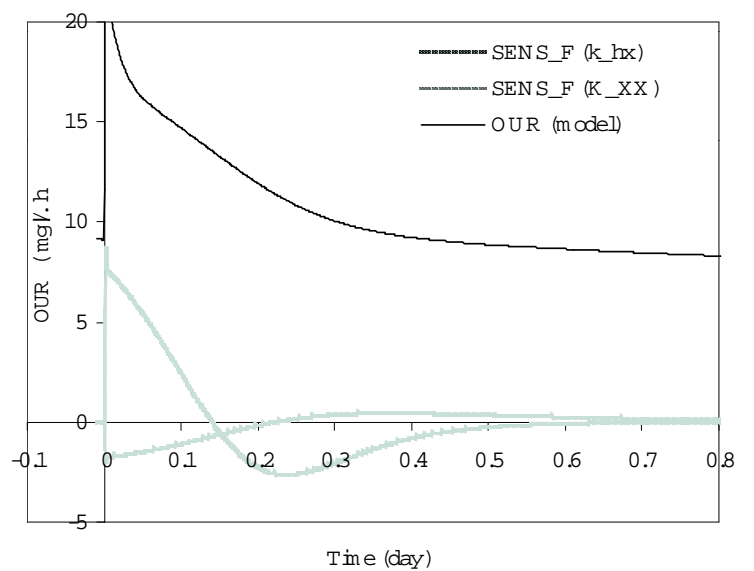

Figure 10

Sensitivity analysis of the OUR profile for Run 3

The same figure also gives model outputs for the $S_{S}, S_{H}$ and $X_{S S}$ profiles during the test. It should be noted that both $\mathrm{S}_{\mathrm{S}}$ and $\mathrm{S}_{\mathrm{H}}$ were totally depleted, as could be predicted, after the OUR peak, within the first $0.05 \mathrm{~d}$ of the experiment and $\mathrm{X}_{\mathrm{SS}}$ totally controlled the rest of the OUR profile, through hydrolysis as the rate limiting mechanism. The model evaluation was validated, as shown in Fig. 9, for practically the same kinetic coefficients $\left(k_{h X}=0.8 \mathrm{~g}\right.$ $\mathrm{COD} / \mathrm{g} \mathrm{COD} \cdot \mathrm{d} ; \mathrm{K}_{\mathrm{xx}}=0.04 \mathrm{gCOD} / \mathrm{g} \mathrm{COD}$ ) for the OUR profile characterising the second test.

Together with the simulation studies, a sensitivity analysis was performed, in accordance with AQUASIM (Reichert, 1994), in order to assess the individual effect of kinetic coefficients defining hydrolysis of particulate COD. Figure 10 gives the results of the analysis for the OUR profile associated with the first test on settled sewage (Run 3). It should be first noted that the absolute relative function used in the sensitivity analysis is structured to yield variations in OUR values inflicted by a 100\% change in the selected hydrolysis rate constants. In this framework both coefficients exert significant impact at the beginning of the experiment on the initial descending part of the OUR profile. A 100\% increase in the value of $\mathrm{k}_{\mathrm{hX}}$ selected as $0.7 \mathrm{~d}^{-1}$ for the evaluation is shown to affect the initial OUR value by around $8 \mathrm{mg} / \mathrm{l} \cdot \mathrm{h}$. An opposite impact of $2 \mathrm{mg} / \mathrm{l} \cdot \mathrm{h}$ is observed for $\mathrm{K}_{\mathrm{Xx}} \cdot \mathrm{k}_{\mathrm{hX}}$ remains dominantly effective on the entire profile with a negative effect after $0.13 \mathrm{~d}$. since the biodegradable substrate represented by the total area under the OUR curve must stay constant. The lower impact of $\mathrm{K}_{\mathrm{Xx}}$ becomes gradually negligible after $0.3 \mathrm{~d}$ within the next OUR plateau. Figure 8 also indicates segments of the OUR profile which are not appreciably affected by the coefficients. The analysis identifies these segments as the portion of the experiment between 0.13 to $0.2 \mathrm{~d}$ and after $0.6 \mathrm{~d}$. The last segment may be explained by the fact that no slowly biodegradable substrate remains after $0.6 \mathrm{~d}$ and the hydrolysis rate equation presumably converges to zero. These results are also applicable for the second test (Run 4).

The effect of $\mathrm{X}_{\mathrm{SS}}$ and $\mathrm{X}_{\mathrm{H}}$ was also tested by model simulation with the same data used for calibration and validation. Figure 11 gives the results obtained for Run 3. As previously evaluated, OUR is highly sensitive to $X_{S S}$, but $X_{H}$ has a relatively minor effect on the overall OUR profile. In other words, it is imperative to differentiate settled particulate COD into its slowly biodegradable and active heterotrophic biomass fractions, mainly for the assessment of the real $X_{\mathrm{SS}}$ level, but the resulting $\mathrm{X}_{\mathrm{H}}$ does not seem to be equally critical for model evaluation. This result may find a better explanation with the rate expression for hydrolysis, rearranged as below: 

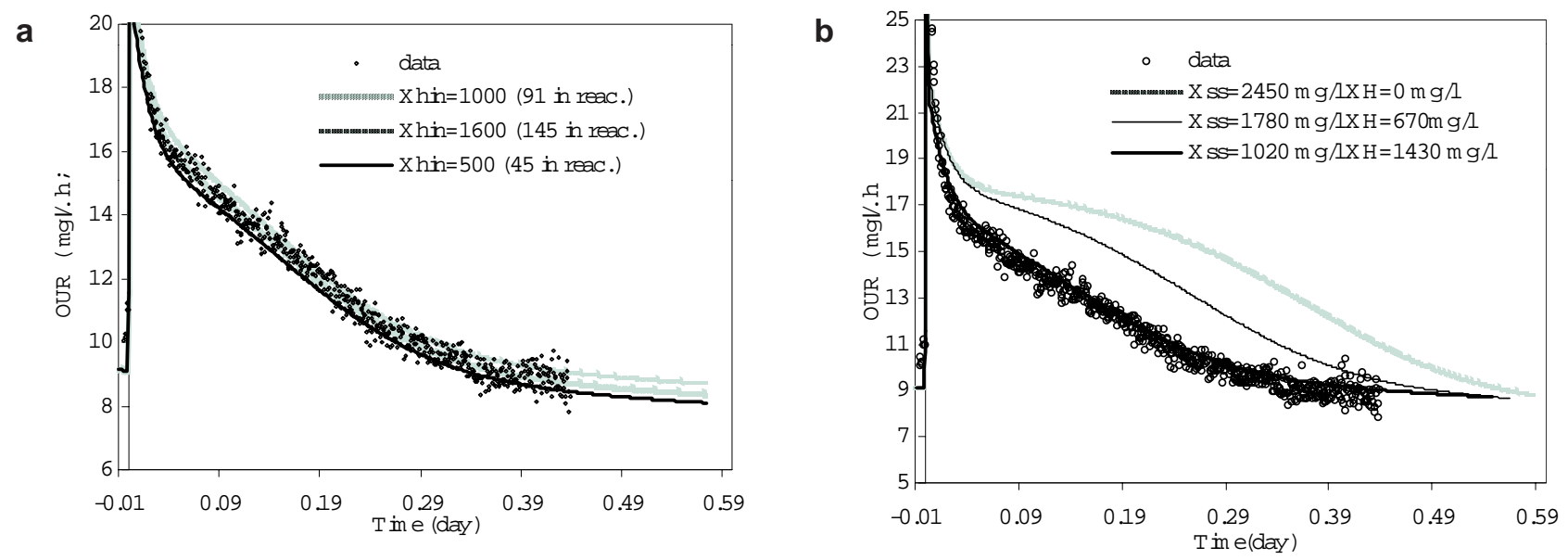

Figure 11

The effect of $X_{H}$ and $X_{S S}$ on the OUR profile for Run 3. (a) The effect of $X_{H}$ (b) The effect of $X_{S S}$
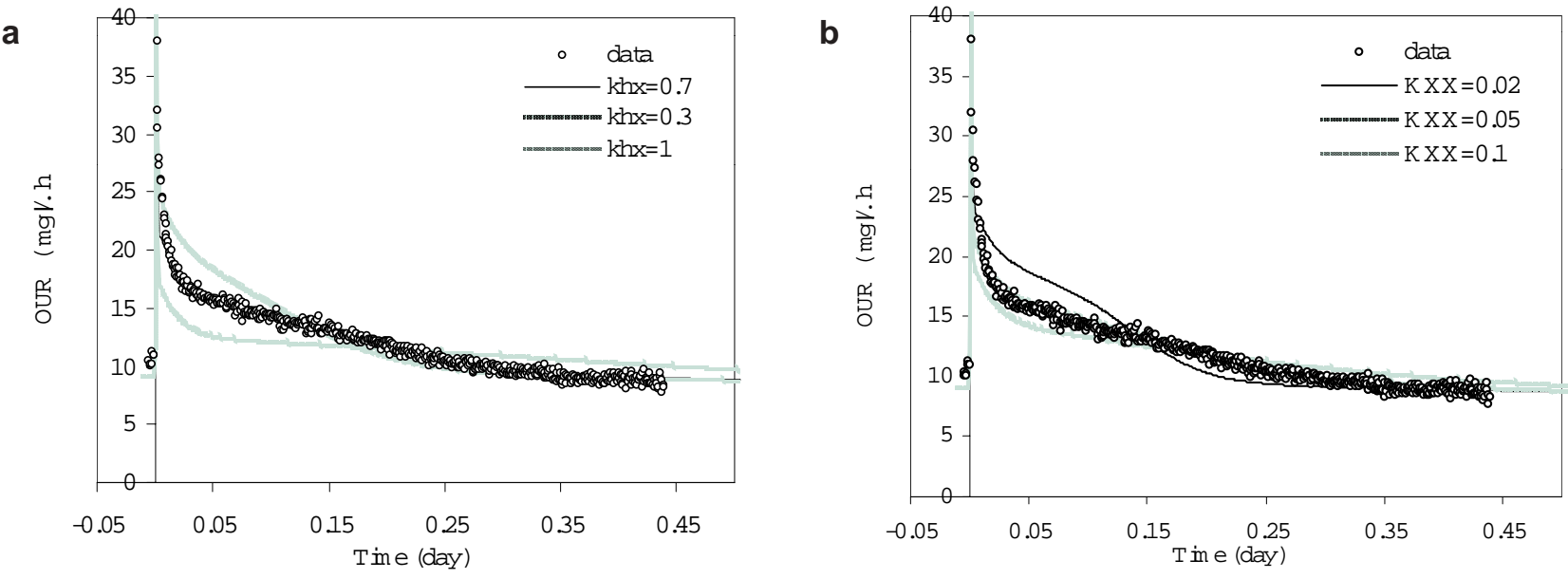

Figure 12

The effect of $k_{h x}$ and $K_{x x}$ on the OUR profile for Run 3. (a) The effect of $k_{h x}$ (b) The effect of $K_{x x}$

$$
\frac{\mathrm{dX} s s}{\mathrm{dt}}=\mathrm{k}_{\mathrm{xs}} \frac{\mathrm{Xss}_{\mathrm{ss}}}{\mathrm{Kxx} \cdot \mathrm{X}_{\mathrm{H}}+\mathrm{X}_{\mathrm{ss}}} \mathrm{X}_{\mathrm{H}}
$$

This expression indicates that increasing $\mathrm{X}_{\mathrm{H}}$ exerts a direct action on the hydrolysis of $\mathrm{X}_{\mathrm{sS}}$, but at the same time, it has a tampering effect through a higher apparent half-saturation coefficient, $\mathrm{K}_{\mathrm{XX}} \mathrm{X}_{\mathrm{H}}$.

Similarly, the results of the sensitivity analysis were visualised for Run 3, by means of model simulation. The validity of the selected $\mathrm{k}_{\mathrm{hX}}$ of $0.7 \mathrm{~g} \mathrm{COD/g} \mathrm{COD.d,} \mathrm{within} \mathrm{the} \mathrm{set} \mathrm{of} \mathrm{tested} \mathrm{values}$ varying in the narrow range of 0.3 to $1.0 \mathrm{~g} \mathrm{COD} / \mathrm{g} C O D \cdot d$, could be easily depicted in Fig. 12a, from significant deviations from the experimental data, especially on the descending section of the OUR profile. A similar confirmation could also be obtained, as given in Fig. $12 b$, for $\mathrm{K}_{\mathrm{xx}}=0.05$ emerging as the most appropriate value among the tested range. The same validity evaluation proved equally successful for Run 4.

The set of kinetic and stoichiometric coefficients chosen as the appropriate values for the characterisation of settleable COD is outlined in Table 2. The same table also includes similar values associated with filtered COD, reflecting the properties of raw wastewater. Aside from typical values for microbial growth, a significantly slower hydrolysis mechanism is defined for settled $\mathrm{COD}$, with a $\mathrm{k}_{\mathrm{hX}}$ value, less than half the level characterising the hydrolysis of its soluble slowly biodegradable counterpart.

\section{Conclusions}

The following results may be outlined as the concluding remarks of the study:

- The analysis of the OUR profile in an aerated batch reactor may be recommended as a reliable procedure for the experimental assessment of the biodegradation characteristics of settleable organics, in the same conceptual framework used for the kinetic evaluation of domestic sewage.

- Model evaluation of the OUR profile should account for the active heterotrophic biomass content that is found to constitute a significant fraction of the settled COD.

- The experimental evaluation defines a significantly slower mechanism for settled COD, less than half the level characterising the hydrolysis of the slowly biodegradable COD commonly associated with domestic sewage. This observation may be used as an indication to highlight settleable COD as an independent parameter for sewage, but it certainly requires confirmation by further experimental support. 


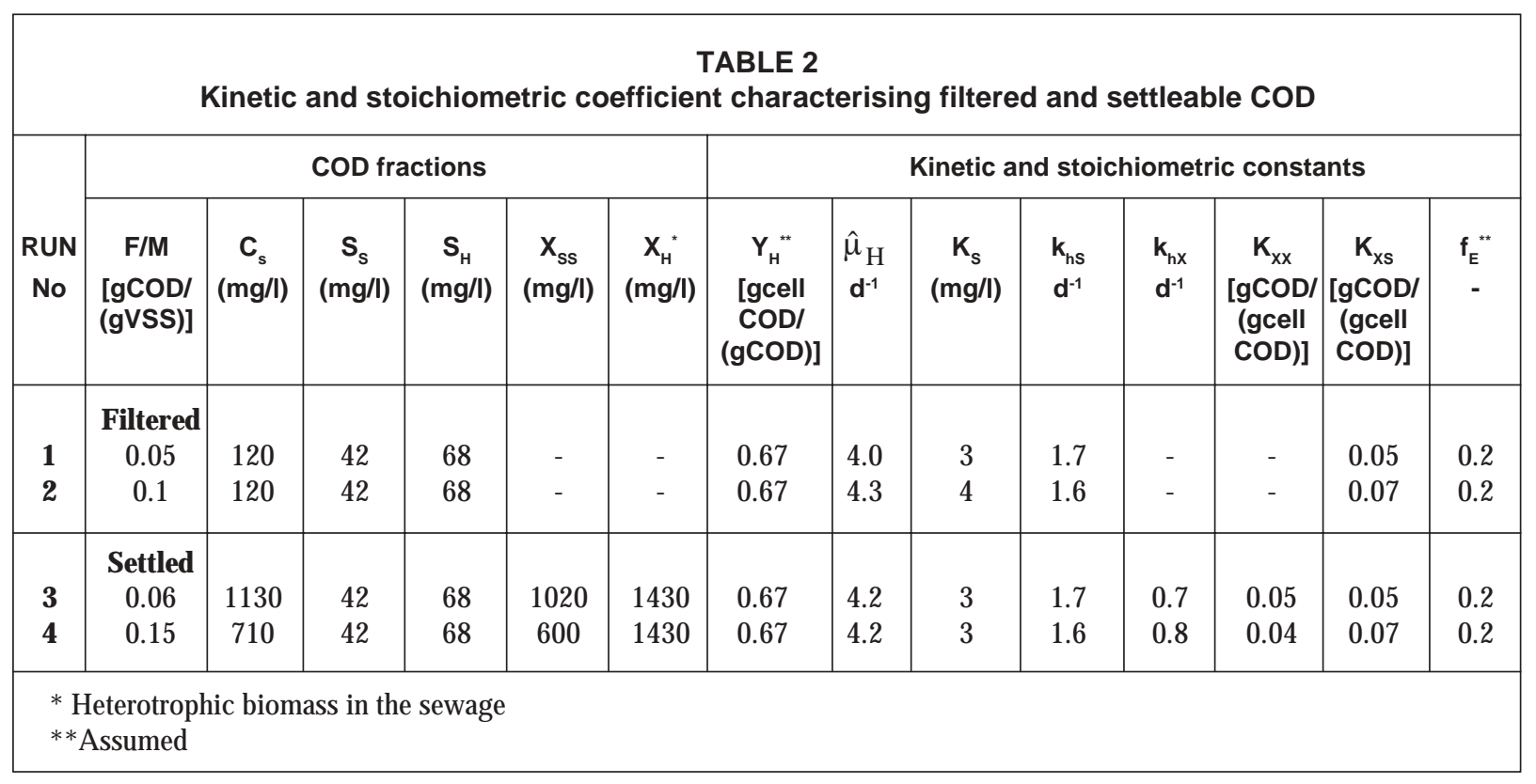

\section{Acknowledgments}

This study was conducted as part of the sponsored research activities of The Environmental Biotechnology Centre of the Scientific and Technical Council of Turkey. The Research and Development Fund of the Istanbul Technical University also supported it.

\section{References}

ANDREASEN K, PETERSEN G, THOMPSEN H and STRUBE R (1997) Reduction of nutrient emission by sludge hydrolysis. Water Sci. Technol. 10 79-85.

BANNISTER SS and PRETORIUS WA (1998) Optimization of primary sludge acidogenic fermentation for biological nutrient removal. Water SA 24 (1) 35-41.

BRINCH PP, RINDEL K and KALB K (1994) Upgrading to nutrient removal by means of internal carbon from sludge hydrolysis. Water Sci. Technol. 29 (12) 31-40.

EKAMA GA, DOLD PL and MARAIS GvR (1986) Procedures for determining influent $C O D$ fractions and the maximum specific growth rate of heterotrophs in activated sludge systems. Water Sci. Technol. 18 91-114.

GRADY LCP, DAIGGER G and LIM HC (1999) Biological Wastewater Treatment ( $2^{\text {nd }}$ edn.), Marcel Dekker Publishing Inc., Newyork, USA. $1076 \mathrm{pp}$.

HATZICONSTANTINOU GJ, YANNAKOPOULOS P and ANDREAKIS A (1996) Primary sludge hydrolysis for biological nutrient removal. Wat. Sci. Tech. 34 (1-2) 417-423.
HENZE M, GRADY CPL JR, GUYER W, MARAIS GvR and MATSUO T (1987) Activated Sludge Model No:1, IAWPRC Scientific and Technical Report No.1, IAWPRC, London.

HENZE M (1992) Characterisation of wastewater for modelling of activated sludge processes. Water Sci. Technol. 25 (6) 1-15.

MOSER-ENGELER R, UDERT KM, WILD D and SIEGRIST H (1998) Products from primary sludge fermentation and their suitability for nutrient removal. Water Sci. Technol. 38 (1) 265-273.

OKUTMAN D, KARAHAN GÜL Ö, ORHON D and SPANJERS H (2002) Characterisation and mass balance of domestic sewage for biodegradability (submitted for publication).

ORHON D and ARTAN N (1994) Modelling of Activated Sludge Systems. Technomic Publ. Co. Inc., Lancaster, PA, USA.

ORHON D, ATES E, SÖZEN S and UBAY ÇOKGÖR E (1997) Characterization and COD fractionation of domestic wastewater. Environ. Pollut. 95 (2) 191-204.

PITMAN (1995) Practical experiences with biological nutrient removal on full-scale wastewater treatment plants in South Africa. International Konferenz zur Vermehrten Biologischen Phosphore.

REICHERT P, VON SCHULTHESS and WILD D (1995) The use of AQUASIM for estimating parameters of activated sludge models. Water Sci. Technol. 31 (2) 135-147.

REICHERT P (1994) AQUASIM-A tool for simulation and data analysis for aquatic systems. Water Sci. Technol. 30 (2) 21-30.

STANDARD METHODS(1998) Standard Methods for the Examination of Water and Wastewater $\left(20^{\text {th }}\right.$ edn.), American Public Health Association/ American Water Works Association/ Water Environment Federation, Washington D.C., USA.

SOLFRANK U and GUJER W (1991) Characterization of domestic wastewater for mathematical modelling of the activated sludge. Water Sci. Technol. 23 1057-1066. 
